\title{
New data on distribution, morphology and taxonomy of phoronid larvae (Lophophorata: Phoronida)
}

\begin{abstract}
E.N. Temereva
Department of Invertebrate Zoology, Biological faculty, Moscow State University, Moscow 119992, Russia.

e-mail:temereva@mail.ru

ABSTRACT: Phoronids have worldwide distribution and are found in almost all seas of the World Ocean. Frequently phoronid larvae (actinotrochs) comprise a significant proportion of the total zooplankton biomass that makes their studies a very important source of information for ecologists, planktonologists, and zoologists. Investigations of phoronid larvae are interesting due to their relation to affiliation of this phylum and other main groups of Bilateria. Identification of all species and stages is difficult due to the paucity of published information regarding phoronid larvae. The descriptions of morphology and microscopic anatomy of actinotrochs found in Mediterranean and Black seas, Sea of Okhotsk, Sea of Japan, close to Reunion Island and in the Puget Sound are given. For the first time, the larvae that presumably belong to Phoronopsis albomaculata and $P$. californica are described. The morphological and behavioral features of two main types of actinotrochs are formulated. A complete key for identification of all actinotrochs known by now is developed.
\end{abstract}

KEY WORDS: Phoronida, larvae, actinotrocha, morphology, identification key.

\section{Новые данные о распространении, морфологии и таксономии личинок форонид (Lophophorata: Phoronida)}

\section{Е.Н. Темерева}

Кафедра зоологии беспозвоночных биологического факультета Московского государственного университета им. М.В. Ломоносова, Москва 119991, Россия.

e-mail:temereva@mail.ru

РЕЗЮМЕ: Форониды - тип животного царства, представители которого имеют всесветное распространение и обнаруживаются во всех акваториях Мирового океана. Зачастую личинки форонид - актинотрохи - достигают большой численности и составляют значительную долю зоопланктона, что делает их важным объектом различных гидробиологических, зоологических и экологических исследований. Изучение личинок форонид интересно и позиций сравнительной анатомии и филогении, поскольку положение этой группы на филогенетическом древе Bilateria до сих пор точно не определено. В настоящее время видовая идентификация личинок форонид практически невозможна из-за отсутствия определительных таблиц, под- 
робных описаний и обобщающих сводок. В работе даны подробные описания морфологии и микроскопической анатомии личинок форонид, обнаруженных в Средиземном, Черном, Охотском, Японском морях, у побережья о-ва Реюнион, в зал. Пьюджет Саунд. Впервые описаны личинки, предположительно принадлежащие Phoronopsis californica и P. albomaculata. Выделено два основных типа организации планктотрофных личинок форонид, выявлены их морфологические и поведенческие особенности. Предложен ключ для видовой идентификации личинок.

КЛЮЧЕВЫЕ СЛОВА: ФоронидЫ, личинки, актинотроха, морфология, определительный ключ.

\section{Introduction}

Phoronids were originally described by their larval type, the actinotroch, under the name «Actinotrocha branchiata» (Muller, 1846). Adult phoronids of the genus «Phoronis» were described later (Wright, 1856), and Kovalevsky (1867) made the connection between the larval and adult forms. Early larval stages of phoronids are difficult to identify to species, and overall several late stage actinotrochs and adult phoronid forms have been described as separate 'species'. For the most part, the correspondence between different larval 'species' and adult forms has only been recognized in the last fifty years, and as a result there are several well described larval types for which the adult forms are unknown.

Adult phoronids are found in most of the world's oceans seas and frequently have high both population densities: up to 93000 individuals $/ \mathrm{m}^{2}$ (Emig, 1982) and biomass. The number of described larval 'types' exceeded the number of described adult forms. Particularly, 25 larval morphological types are known for the 12 (undisputed) described adult phoronids (see, for example, Emig, 1982). In plankton, phoronid larvae may reach abundances up to 1000 individuals $/ \mathrm{cm}^{3}$ (per.obs.) and represent of significant proportion of the total zooplankton biomass at certain times of the year. The description and identification of actinotrochs are crucial for understanding this group of animals. Traditionally, comparative anatomists regarded phoronids and deuterostomes as related groups (Masterman, 1898; Remane, 1950; Emig, 1971, 1974;
Siewing, 1974, 1980; Herrmann, 1976, 1986). However, molecular phylogenetic evidence identified phoronids and brachiopods as a monophyletic group within the Lophotrochozoan protostomes as a sister group to Spiralia (Halanych et al., 1995).

Due to the lack of detailed studies, the identification of phoronid larvae is sometimes problematic as indicated in Santagata and Zimmer (2002). This problem can be approached using molecular phylogenetic methods, but it cannot be solved without careful descriptions of larvae from different biogeographical regions of the world.

The purpose of this study was (i) to provide new information on the distribution of several well described species and also to describe in detail several actinotroch types for which the adult form is not known; (ii) to reveal the general patterns of morphology, anatomy and behavior of the two main types of actonotrochs; and (iii) to compose a key for determination of known phoronid larvae.

\section{Material and methods}

Some phoronid larvae were collected by the author in Vostok Bay, Sea of Japan, by applying a planktonic net; other larvae were found in plankton samples that were collected during expeditions and being kept at the Department of Invertebrate Zoology of Moscow Univercity, at Zoological Museum of Moscow University etc. Larvae were preserved in a $4 \%$ formaldehyde solution. For the studies, they were cleaned by distilled water and transferred to $70 \%$ ethanol. 
Intact larvae were investigated in light microscopes (Olympus BX51 and Leica MZ6) and photographed with a digital camera Olympus Camedia. Some specimens were rinsed in alcohol and embedded in paraplast. Sagittal and cross-sections were made with a Leica rotary microtome, which then were stained with Caracci haematoxylin. Sections were examined with Olympus BX51, photographed with Olympus Camedia. Some larvae were prepared for scanning electron microscopy (SEM). Specimens for SEM were fixed in a $4 \%$ formaldehyde solution, cleaned in distilled water, dehydrated in an ethanol series, critical-point dried, mounted on stubs with double-stick tape, sputtercoated with platinum-palladium, and examined with a CamScan S2.

\section{Results}

All phoronid larvae (actinotrochs) have common body organization. At the description of actinotrochs we used the terminology accepted in the Emig's work (1975). Larval body can be divided into three regions: preoral lobe (preoral hood), collar region with tentacles, and the trunk. Each body region contains a corresponding coelomic cavity. Larvae of genus Phoronis Wright, 1856 and Phoronopsis Gilhrist, 1907 differ in the shape of preoral coelom. As assumed in our previous work (Temereva, Malakhov, 2004), larvae belonging to the genus Phoronospsis possess a closed cylindricalshaped preoral coelom lying under the apical plate. On the total preparations well visible, that protocoel cavity is in Phoronopsis larvae delimited by two septums (dorsal and ventral), which intersect the preoral lobe from apical plate to esophagus. Zimmer (1978, p. 38) discussed the structure of preoral coelom in phoronid larvae and noted that the larvae of Phoronopsis californica Hilton, 1930, P. viridis Hilton, 1930 and $P$. harmeri Pixell, 1912 possess «diminutive protocoel», that in Zimmer's photos look like cylinder under the apical plate (see p. 28-31 and Fig. 5, 6, 8). The larvae belonging to the genus Phoronis have another form of preoral coelom (see Ikeda, 1901, Fig. 45; Goodrich,
1903; Zimmer, 1964, Fig. 45; Herrmann, 1976, Abb. 9) or have no coelomic cavity in preoral lobe at all (Bartolomaeus, 2001).

Only competent actinotrochs can be identified to species with any degree of certainty. Before metamorphosis, the actinotrochs of each species have a fixed body length, and possess the fixed number of tentacles and blood masses. In some larvae there are the juvenile tentacles nascent before metamorphosis. Frontal organ (or piriform organ - conical protrusion on the ventral midline of the preoral lobe) develops at competence in some larvae. The presence of juvenile tentacles and piriform organ is diagnostic feature.

Non-competent stages of actinotrochs are often found. In this case, only the descriptions of these stages are given. For competent larvae diagnostic features and other interesting morphological characters are enumerated.

1. Actinotrochs of the Mediterranean Sea (close to the coast of Morocco) (Figs 1A; 2A; 3A-C).

Larvae were collected in August 1997. They belong to two phoronid species: Phoronopsis harmeri and Phoronis muelleri Selys-Longchamps, 1903.

1.1. P. harmeri larvae from the Mediterranean Sea have all the same characteristics of Actinotrocha harmeriZimmer, 1964, described by us from the Sea of Japan (description see below).

1.2. Larvae belonging to Phoronis muelleri are called Actinotrocha branchiata Müller, 1846.

DESCRIPTION. Larvae are transparent(Fig. 2A). Through transparent surface evidently that closed coelomic cavity in preoral lobe is absent (Fig. 3A). At the stage with 32 tentacles, larvae have a $1.2 \mathrm{~mm}$ body length. The presumptive juvenile tentacles and frontal organ are present. The body length of larvae with 42 tentacles is $2.1 \mathrm{~mm}$ (Fig. 2A). Oral field is spacious (Figs $2 \mathrm{~A}, 3 \mathrm{~A}$ ) as compared to other actinotrochas larvae (see Fig. 2). Larval tentacles are thin and long; and under their bases thick and short juvenile tentacles are situated (Fig. 2A, 3B). A single corpuscle mass shaped like a horseshoe is 


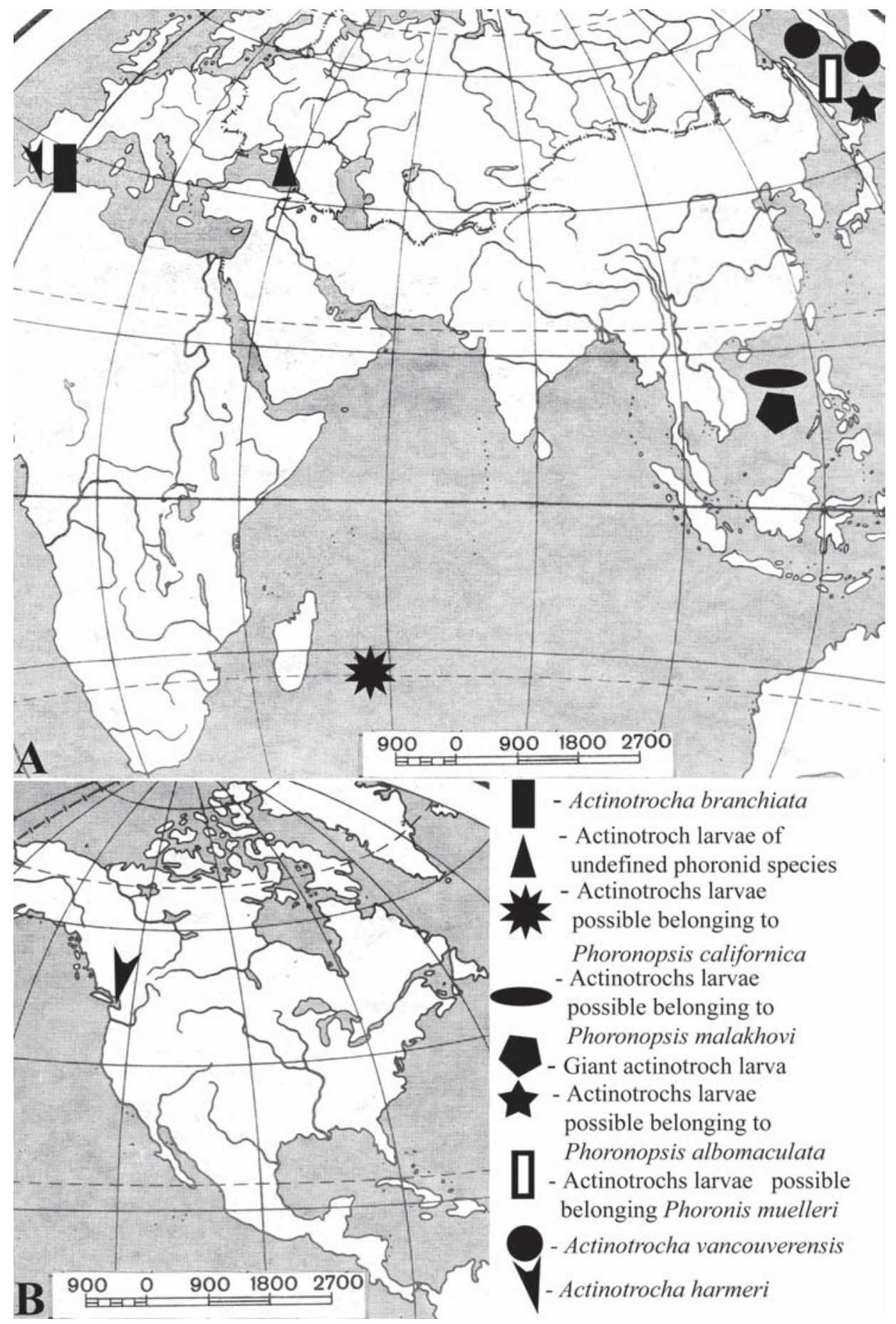

Fig. 1. Maps of new records of phoronid larvae.

A - a part of Eastern hemisphere. B - a part of Western hemisphere.

Рис. 1. Новые находки личинок форонид (географические карты).

A - часть восточного полушария. В - часть западного полушария. 


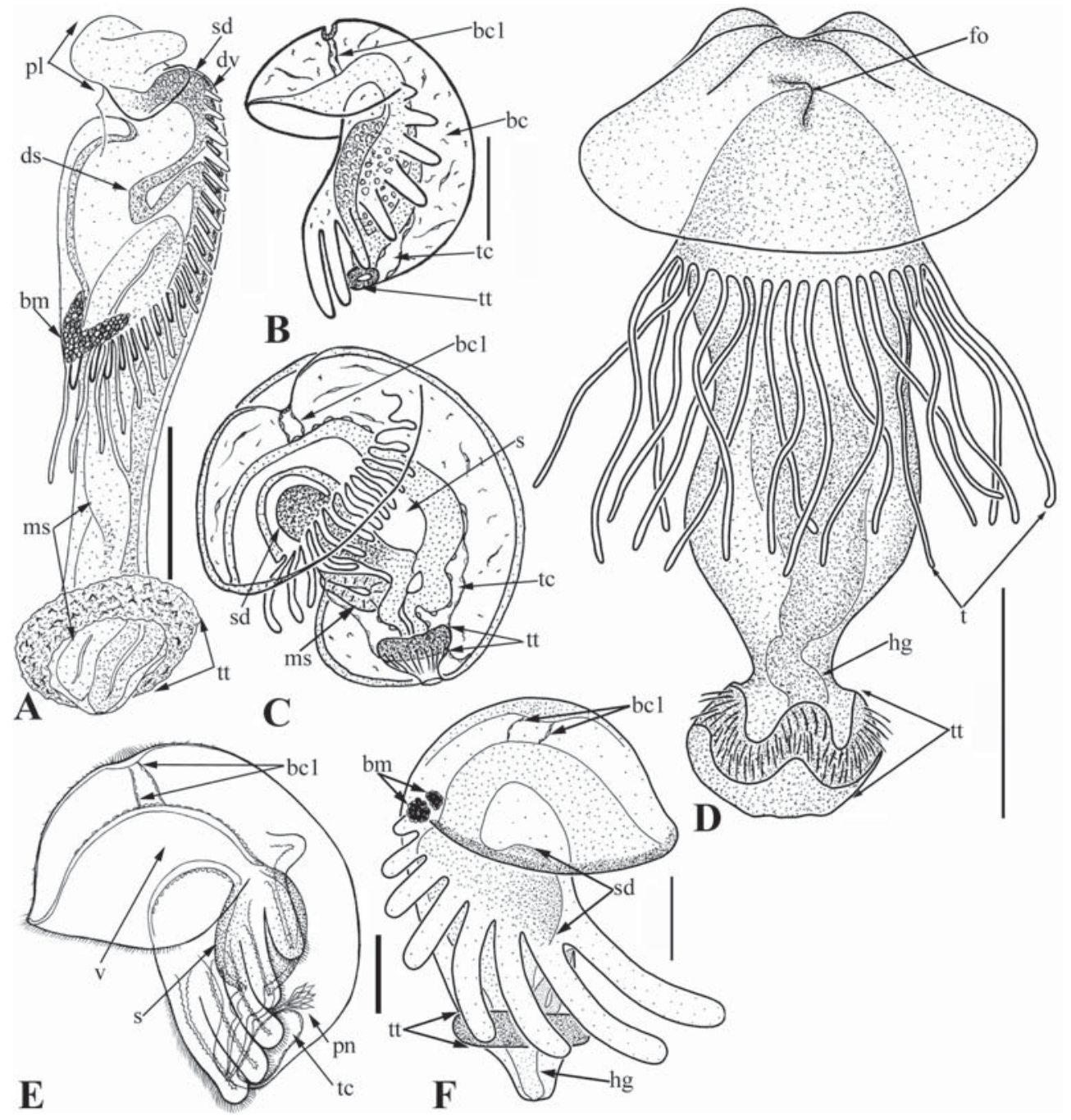

Fig. 2. Phoronid larvae (line drawings of fixed animals).

A - Phoronis muelleri larva discovered close the coast of Morocco. B, C - larvae possibly belonging to Phoronopsis californica (B - larva with 16 tentacles; C - larva with 28 tentacles). D - giant actinotrocha. E - larva possibly belonging to Phoronopsis malakhovi. F - larva possibly belonging to Phoronopsis albomaculata. Abbreviations: bc 1 - border/borders of preoral coelom; bc — blastocoel; bm — blood mass; ds — dorsal septum; dv — dorsal vessel; es - esophagus; fo — frontal organ; hg — hindgut; ms - metasomal sac; $\mathrm{pl}$ - preoral lobe, pn — protonephridium; $\mathrm{s}$ — stomach; $\mathrm{sd}$ — stomach diverticulum; $\mathrm{t}$ — tentacles; $\mathrm{tc}$ — trunk coelom; $\mathrm{tt}$ — perianal ciliated ring; $\mathrm{v}$ — vestibulum. Scale bars: A $-0.5 \mathrm{~mm}$; B-C, E-F $-0.1 \mathrm{~mm}$; D $-1 \mathrm{~mm}$.

Рис. 2. Личинки форонид (рисунки фиксированных животных).

A - личинка Phoronis muelleri, обнаруженная вблизи побережья Марокко. В, С - личинка, возможно, принадлежащая Phoronopsis californica (B - на стадии 16 щупалец; C - на стадии 28 щупалец). D - гигансткая актинотроха. Е - личинка, возможно, принадлежащая Phoronopsis malakhovi. F - личинка, возможно, принадлежащая Phoronopsis albomaculata. Обозначения: bc1 - граница(ы) предротового целома; bc - бластоцель; bm — скопление эритроцитов; ds — дорсальная септа желудка; dv — дорсальный сосуд; еs — пищевод; fo — фронтальный орган; hg — задняя кишка; ms — метасомальный мешок; pl — преоральная лопасть; pn протонефридий; s — желудок; sd — дивертикул желудка; $\mathrm{t}$ — щупальца; $\mathrm{tc}$ — туловищный целом; $\mathrm{tt}$ — телотрох; v - вестибулюм. Масштабы: А - 0,5 мм; В-C, E-F - 0,1 мм; D - 1 мм. 


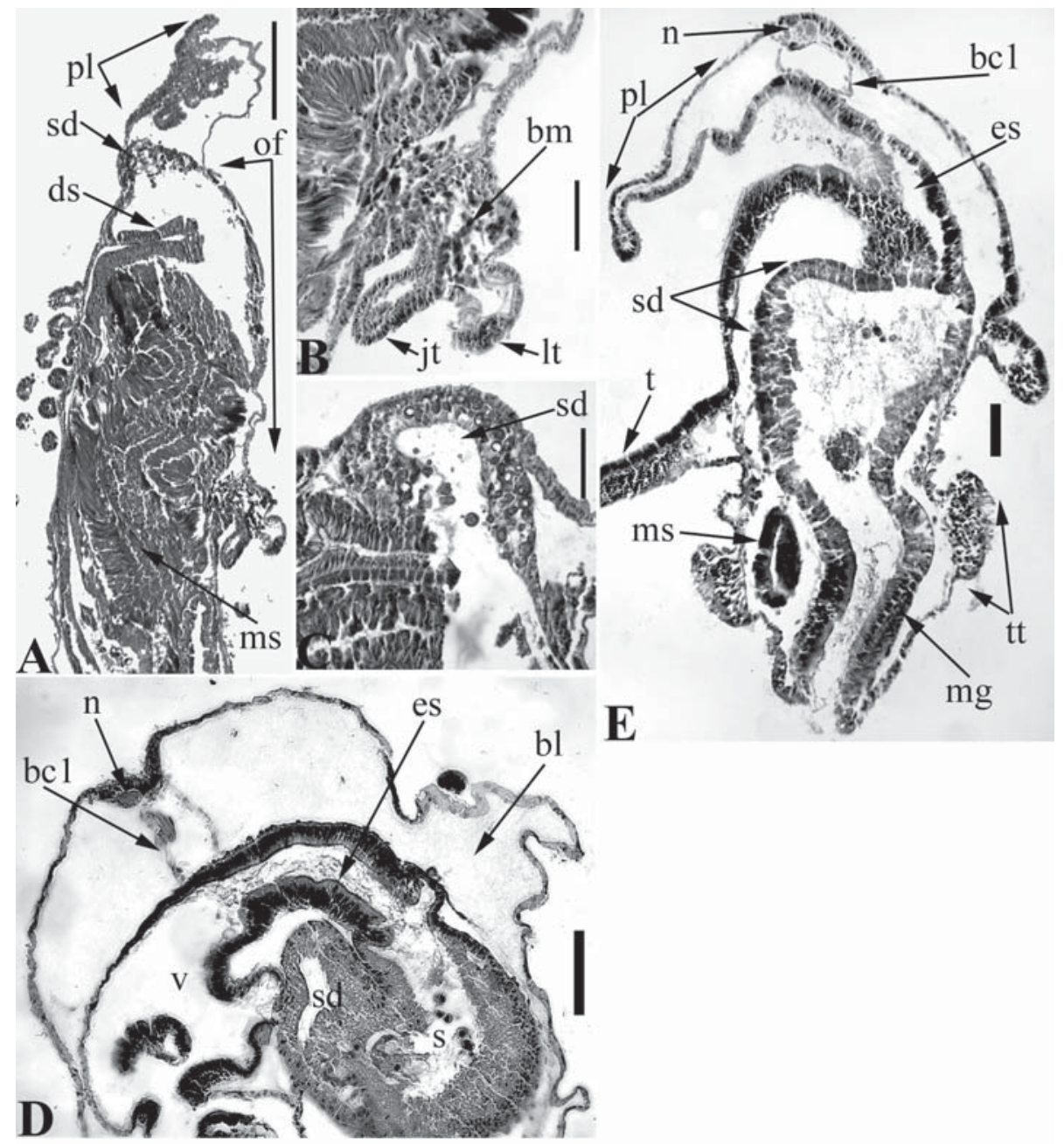

Fig. 3. Histological sections of some phoronid larvae.

A-C - sections of Phoronis muelleri larvae: A - upper part of parasagittal section with small preoral lobe ( $\mathrm{pl}$ ), spacious oral field (of), dorso-lateral stomach diverticulum (sd), dorsal septum into stomach (ds) and large metasomal sac (ms); $\mathrm{B}$ - section through larval (lt) and juvenile (jt) tentacles and ventral blood mass; C - longitudinal section through stomach diverticulum (sd). D - sagittal section of larva with 28 tentacles discovered nearly the Reunion Island. E sagittal section of larva discovered in South-Kurilskiy Strait. Abbreviations: bc1 - border of preoral coelom; bl blastocoel; es - esophagus; $\mathrm{n}$ - neuropile; $\mathrm{mg}$ - midgut; $\mathrm{ms}$ - metasomal sac; $\mathrm{pl}$ — preoral lobe, $\mathrm{s}$ — stomach; $\mathrm{sd}$ - stomach diverticulum; $\mathrm{t}$ - tentacles; $\mathrm{tt}$ - perianal ciliated ring; $\mathrm{v}$ - vestibulum. Scale bars: A - $0.3 \mathrm{~mm}$; B, $\mathrm{C}-0.1 \mathrm{~mm}$; D $-50 \mathrm{~mm} ; \mathrm{E}-30 \mathrm{~mm}$.

Рис. 3. Гистологические срезы личинок форонид.

A-C - продольные срезы через личинку Phoronis muelleri, обнаруженную вблизи побережья Марокко: А верхняя часть парасагиттального среза, видны: маленькая преоральная лопасть (pl), протяженное оральное поле (of), дорсо-латеральный дивертикул желудка (sd), дорсальная септа в желудке (ds) и часть метасомального кармана (ms); В - срез через личиночные (lt) и дефинитивные (jt) щупальца и вентральное скопление эритроцитов; С: Продольный срез через дивертикул желудка. D - сагиттальный срез личинки на стадии 28 щупалец, обнаруженной вблизи о-ва Реюнион. Е - сагиттальный срез через личинку, обнаруженную в ЮжноКурильском проливе. Обозначения: bc 1 - граница предротового целома; bl — бластоцель; еs — пищевод; $\mathrm{n}$ нейропиль апикального органа; $\mathrm{mg}$ - средняя кишка; $\mathrm{ms}$ - метасомальный мешок; $\mathrm{pl}$ — преоральная лопасть; s — желудок; sd — дивертикул желудка; $\mathrm{t}$ — щупальца; $\mathrm{tt}$ — телотрох; $\mathrm{v}$ — вестибулюм. Масштабы: А — 0,3мм; $\mathrm{B}, \mathrm{C}-0,1$ мм; D - 50 мкм; $\mathrm{E}-30$ мкм. 
situated on the ventral and ventrolateral sides of the stomach (Fig. 2A). Blood corpuscles also lie in the blastocoelic space near the bases of the juvenile and larval tentacles (Fig. 3B). There are two dorsolateral stomach's diverticula with thick and vacuolated walls (Figs 3A, C). The dorsal wall of stomach forms a long septum protruding into stomach cavity (Figs 2A, 3A). What will become the muscular and ampullar regions of the adult trunk (metasomal sack) occupies the most of body volume (Fig. 3A).

DIAGNOSTIC FEATURES. Larva is transparent, before metamorphosis body length is ca. $2 \mathrm{~mm}$, number of tentacles is more than 30 . Cylindrical protocoel is absent. There are two blood masses situated on ventrolateral sides of the stomach, they can fuse into one mass before metamorphosis. Larva possesses juvenile tentacles. Stomach diverticulum is paired. Frontal (pirifom) organ is present.

COMMENT. This larval form belongs to Phoronis muelleri and is identical to the forms described by Wagner (1847) and Masterman (1898).

2. Actinotrochs of the Indian Ocean (close Reyunion Island) (Figs 1A; 2B-C, 3D)

Larvae were collected in June 2005. Tentative identification for this larval type is Phoronopsis californica.

DESCRIPTION. Larvae are transparent (Figs 2B-C). A closed coelomic cavity is found in the preoral hood under the apical plate (Figs 2B-C, 3D). Larvae with 16 tentacles have a body length of $0.25-0.30 \mathrm{~mm}$, and a diameter of preoral lobe of $0.2 \mathrm{~mm}$ (Fig. 2B). Larvae with 26-28 tentacles are $0.40-0.45 \mathrm{~mm}$ in length (Fig. 2C). As an artifact of fixation, the perianal ciliated ring (telotroch) was drawn into the body by contraction of the muscles of the trunk, and perhaps the length of this larval type is estimated to be approximately $0.5 \mathrm{~mm}$ (Fig. 2C). The diameter of preoral lobe is $0.3 \mathrm{~mm}$. Larval tentacles are very short and thin, and their diameter is not more than $0.03 \mathrm{~mm}$. Stomach's diverticulum is unpaired (Fig. 3D); and it's walls form a ventral septum into stomach. There is a small metasomal sac. Blood corpuscle masses are lacking. The borders of trunk coelom are seen through the integument (Fig. 2C). The blastocoelic space occupies most of the volume of the preoral hood (Fig. 3D) and larval body (Fig. 2C).

COMMENT. These larvae belong to the genus Phoronopsis because possessing a closed cylindrical-shaped coelomic cavity in preoral lobe under apical plate. Only two species of phoronids have been described near Madagascar Island, Phoronopsis albomaculata Gilchrist, 1907 and P. californica (Emig, 2009). These larvae seem to belong to $P$. californica. The larvae found close to Reunion Island are very young; they even do not have blood mass. Usually phoronid larvae grow up in two times beginning from moment of blood corpuscles appear to competent stage. If to extrapolate this observation to the larvae discussed, they might have a body length more than $1 \mathrm{~mm}$ and about 56 tentacles. It is the largest number of tentacles known among phoronid larvae. As compared with larvae, adult Phoronopsis californica possessing ca. 1500 tentacles has the largest number among adult phoronids (Emig, 1979).

Note that in the Zimmer's work (1978) there is a photo (Fig. 6) of «24-tentacled P. californica larva near metamorphosis». The larval body length is $0.7 \mathrm{~mm}$ before metamorphosis. This larva belongs to the genus Phoronopsis because there is a cylindrical protocoel under apical plate. Before metamorphosis this larva possesses different ratio between number of tentacles and body length in comparison with larvae described by us.

\section{Actinotrochs of the South-China Sea} (Figs 1A; 2D; 4).

In the South-China Sea comparatively large actinotroch larvae (Temereva et al., 2006) and early larval stages were found.

3.1. The giant actinotroch larva was found in planktonic samples taken in September 2005 at the place with coordinates $12^{\circ} 27^{\prime} \mathrm{N}, 110^{\circ} 01^{\prime} \mathrm{E}$ on a depth of $10 \mathrm{~m}$.

DESCRIPTION. Larva is transparent. A single horseshoe-shaped spacious red blood corpuscle mass is situated in the collar region on the ventral and ventrolateral side of the stomach wall. The epithelium of perianal ciliated ring is 
pigmented and in life it has a yellowy-brown color. The body length of the fixed larva is 3.5 $\mathrm{mm}$; the diameter of preoral lobe is $2 \mathrm{~mm}$ (Fig. 2D). Actinotrocha has 52 thin tentacles up to 1.4 $\mathrm{mm}$ long and ca. $25 \mathrm{~m}$ in diameter. In the centre of preoral lobe there is a deep depression on the pole that corresponds to a site of apical organ (apical neural plate/larval brain) (Fig. 2D). In the middle line of preoral lobe there is a small hillock that corresponds to a site of frontal (or piriform) organ (Fig. 2D).

This larval type possesses some morphological traits that are not typical for other phoronid larvae but found in adult phoronids. There is an epithelial fold under preoral lobe nearly mouth that corresponds to epistom in adult phoronids (Fig. 4A). In the basis of epistom, a closed coelomic cavity lies (Fig. 4A). It is a preoral coelom (protocoel). The larva possesses one veritable blood vessel: the erythrocytes surrounded by vascular walls (Fig. 4B). In addition, the larva has a primordial gonad that is situated on the ventral mesentery and is represented by small primordial germ cells (possible oocytes) surrounded by follicular cells (Fig. 4C).

COMMENT. Larva can be tentatively identified to the genus Phoronopsis because it has closed cavity of preoral coelom. Details about the giant Actinotrocha and phenomenon of the large larvae are discussed previously (Temereva et al., 2006). I have not included giant larva in the key for phoronid larvae, because it has some precociously developed adult characters but not has some larval characters, for example, blood masses.

3.2. Young actinotrochs larvae were found in planktonic samples taken in August 1989 at the place with coordinates $12^{\circ} 37^{\prime} \mathrm{N}, 109^{\circ} 23^{\prime} \mathrm{E}$ (Figs 1A, 2E).

DESCRIPTION. Larvae are transparent. A cylindrical-shaped closed coelomic cavity lies in the preoral lobe under apical plate (Fig. 2E). Body length is $0.40-0.50 \mathrm{~mm}$. At this stage, the number of tentacles is either 10 or 12 , larvae have no blood masses, stomach diverticulum and metasomal sack.

COMMENT. These larvae probably belong to Phoronopsis malakhovi Temereva, 2000, described from the same place. These larvae are not included in the key because more or less distinct features have not been found yet.

\section{Actinotrochs of the Black Sea (Figs 1A;} $5,6)$

Larvae were collected in August-September, 2002-2005.

DESCRIPTION. Larvae are transparent. At the stage with 18 tentacles, larvae have a body length of $0.4 \mathrm{~mm}$ (Fig. 5A). The closed cavity under aboral organ in preoral lobe absents (Fig. $6 \mathrm{C})$. The primordia of juvenile tentacles look like small buds under larval tentacles (Fig. 5B). Larval tentacles are somewhat swollen on the distal ends (Fig. 5A). Stomach diverticulum is unpaired (Fig. 6B). There is a ventral epithelial septum into stomach (Fig. 6A). There is a single blood corpuscle mass that is large and situated on the ventral upper side of the stomach diverticulum between the ectoderm epithelium and diverticulum epithelium (Fig. 6B). A frontal organ is present. On the longitudinal sections, it looks like an accumulation of nerve fibers under the ectoderm of preoral lobe (Fig. 6C). The frontal (piriform) organ is not invisible on the external side of preoral lobe. There are three well-developed ciliated bands (Figs 5A, C-D). Preoral ciliated band is turned in hood edge (Fig. 5D). Postoral ciliated band extends along the lateral sides of tentacles (Fig. 5C). Perianal ciliated ring is formed by thick and long cilia (Fig. 5A). There are numerous openings of gland cells surrounded by microvilli on the subumbrella portion of the preoral lobe (Fig. $5 \mathrm{E}$ ). Larva is tentatively identified belonging to the genus Phoronis genera because it has no coelomic cylinder under neural plate (Fig. 6C).

COMMENT. This combination of features has not been reported in other phoronid larvae described in literature. Three phoronid species are known from the Black Sea: P. psammophila Cori, 1889, P. muelleri, P. hippocrepia Wright, 1856. Only P. psammophila and P. muelleri have transparent larvae. Probably larvae described here are varieties of $P$. psammophila larvae: they have 12 tentacles, body length is about $1 \mathrm{~mm}$, there are three blood masses (one ventral and two lateral). But it may be that 


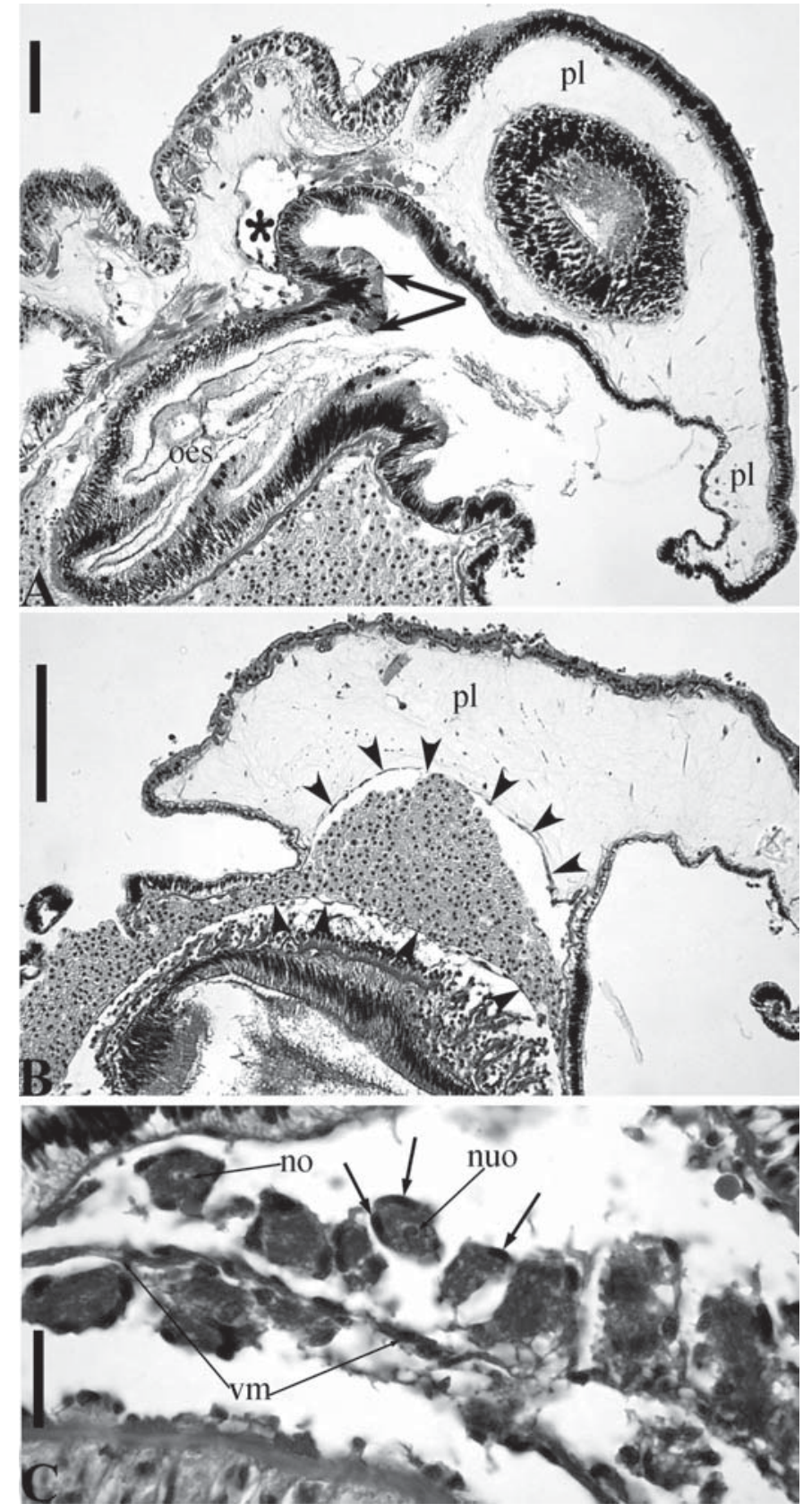

Fig. 4. Histological sections of giant actinotroch larva.

A - sagittal section through preoral lobe (pl), epistome (arrows) and cavity in preoral coelom (asterisk). B — section through ring vessel with complete walls (arrowheads). C - section through the early oocytes (with bright nucleus (no) and black nucleolus (nou)) on ventral mesentery (vm). Scale bars: A, B $-100 \mu \mathrm{m}$; C $-20 \mu \mathrm{m}$.

Рис. 4. Продольные гистологические срезы гигантской актинотрохи.

А - сагиттальный срез через преоральную лопасть (pl), эпистом (указан стрелкой) и предротой целом (обозначен звездочкой). В - срез через кольцевой кровеносный сосуд. Наконечниками указаны полностью сформированные стенки сосуда. С - срез через ранние ооциты (видны прозрачные ядра (nо) и темные ядрышки (nou)), расположенные на участке вентрального мезентерия (vm). Масштабы: А, В - 100 мкм; С - 20 мкм. 

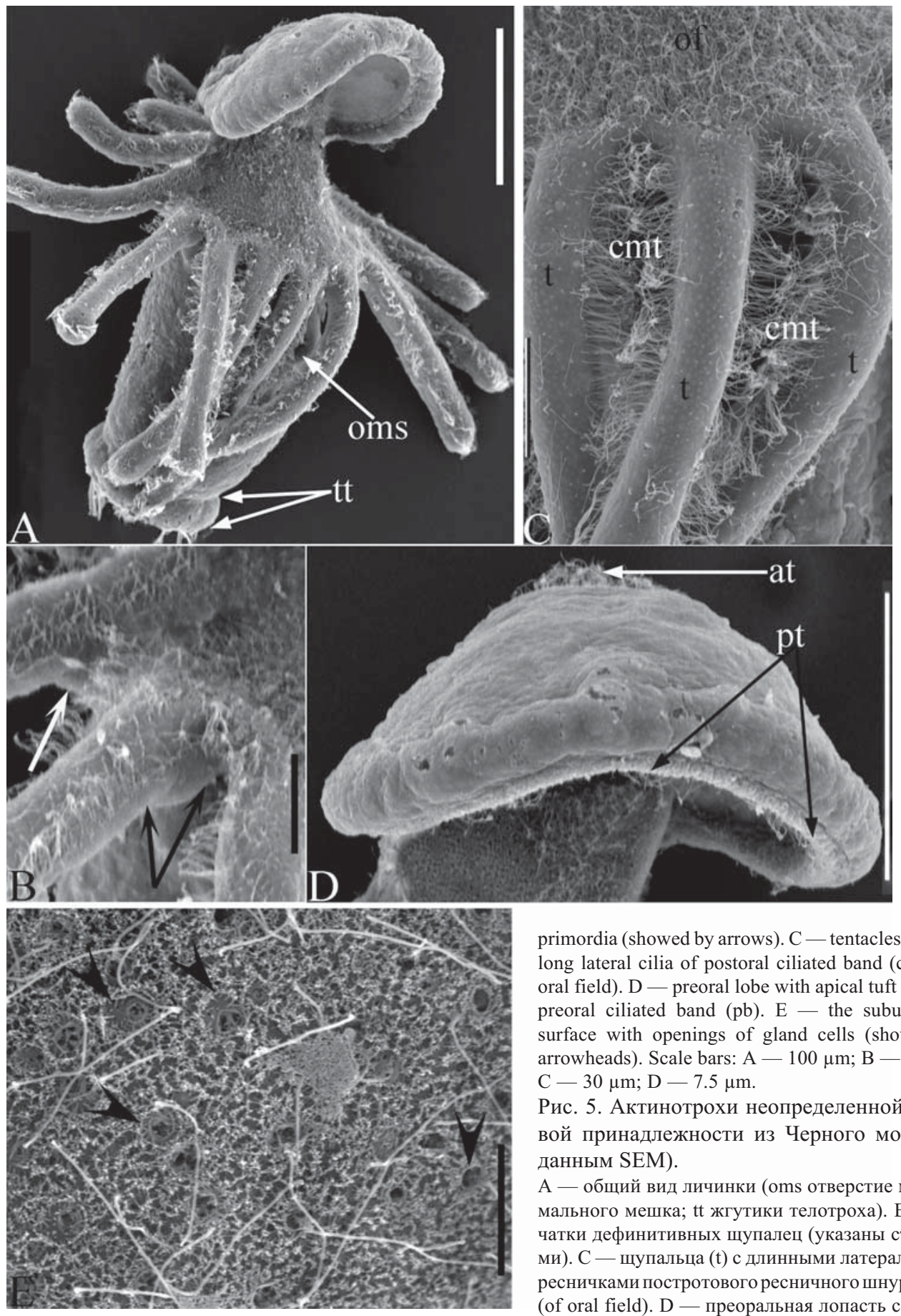

primordia (showed by arrows). C - tentacles ( $\mathrm{t}$ ) with long lateral cilia of postoral ciliated band (cmt) (of oral field). D - preoral lobe with apical tuft (at) and preoral ciliated band $(\mathrm{pb}) . \mathrm{E}$ - the subumbrella surface with openings of gland cells (showed by arrowheads). Scale bars: A $-100 \mu \mathrm{m} ; \mathrm{B}-10 \mu \mathrm{m}$; $\mathrm{C}-30 \mu \mathrm{m} ; \mathrm{D}-7.5 \mu \mathrm{m}$.

Рис. 5. Актинотрохи неопределенной видовой принадлежности из Черного моря (по данным SEM).

A - общий вид личинки (oms отверстие метасомального мешка; $\mathrm{tt}$ жгутики телотроха). В - зачатки дефинитивных щупалец (указаны стрелками). С - щупальца (t) с длинными латеральными ресничками постротового ресничного шнура $(\mathrm{cmt})$ (of oral field). D - преоральная лопасть с темен-

Fig. 5. Actinotroch larvae of unidentified phoronid species from the Black Sea (SEM micrograph).

A - general view of larva (oms opening of matasomal sac; tt cilia of perianal ciliated ring). B - adult tentacles ным султанчиком (at) и предротовым ресничным шнуром (pb). Е - поверхность субумбреллы предротовой лопасти с отверстиями железистых клеток (указаны стрелками). Масштабы: А - 100 мкм; В - 10 мкм; С - 30 мкм; D - 7,5 мкм. 
this larval form represents another undescribed species.

\section{Actinotrochs of the Sea of Japan.}

In the Vostok Bay larvae of three phoronid species were found: another unidentified actintroch (Actinotrocha sp.), Phoronis ijimai Oka, 1897 and Phoronopsis harmeri. We found all of these larval types previously (Temereva, Malakhov, 2004). Their photos and diagnostic features are listed for comparison to other actintroch larval types.

5.1. Actinotrocha sp. (a larva of an unidentified phoronid species) (Figs 7A-C)

DIAGNOSTIC FEATURES. Larvae are opaque. The cylindrical coelomic cavity under the neural plate in preoral lobe is absent. Maximal number of tentacles is 8 (Fig. 7A); the body length at this stage is $0.8 \mathrm{~mm}$. There are three blood corpuscle masses (two ventrolateral ones, at a side of esophagus each; and one on the ventral side of the stomach diverticulum). The stomach diverticulum is unpaired and heavily pigmented (Fig. 7C). Juvenile tentacles are present, but only histological sections can help recognizing them. Frontal (piriform) organ is absent.

COMMENT. The combination of Actinotrocha sp. characteristics is unknown for other phoronid larvae, but there is a striking resemblance between Actinotrocha sp. and A. hippocrepia shown at Fig. 3 in the Zimmer's article (Zimmer, 1991) (compare with Fig. 7A). For example, both Actinotrocha sp. aand A. hippocrepia from Zimmer's figure (Zimmer, 1991) have a wide epithelial belt lacking cilium under tentacles (Fig. 7B). We have discovered that there is amazing similarity between Actinotrocha sp. and A. hippocrepia shown at Fig. 22-1C in the Atlas of Marine Invertebrate Larvae (Johnson, Zimmer, 2002). At the same time, Actinotrocha sp. looks like the larvae of Phoronis pallida Schneider, 1862 (Actinotrocha pallida Schneider, 1862) which are shown in the Santagata's article on Fig. 1A (Santagata, 2002) (compare with Fig. 7C). Therefore, some photos of Actinotrocha sp. are provided here for comparison with other resembling Actinotrocha (Figs 7A-C).
5.2. Actinotrocha vancouverensis Zimmer, 1964 (the larva of Phoronis ijimai) (Fig. 7D)

$P$. ijimai larvae were found in the Sea of Japan, Sea of Okhotsk and in the plankton of East Cost of Kamchatka (Fig. 1A).

DIAGNOSTIC FEATURES. Larvae are opaque, while epithelium of oral field and most part of the trunk is heavily pigmented (Fig. 7D). There are two pairs of pigment sports on the edge of preoral lobe (Fig.7D-insert). Coelomic cylinder in preoral lobe is absent. Maximal number of tentacles is 14 . Body length at this stage is $0.9 \mathrm{~mm}$. There are two blood masses located on the ventrolateral side of stomach diverticulum, which is unpaired. Frontal (piriform) organ is present.

COMMENT. There is misinterpretation of the larvae of Phoronis ijimai Oka, 1897 and Phoronis vancouverensis Pixel, 1912. According to Emig (1979, 2009), P. vancouverensis is a junior synonym of $P$. ijimai. But there are some differences between Phoronis ijimai larvae found in the Vostok Bay and A. vancouverensis described by Zimmer (1964). Phoronis ijimai larvae possess two blood corpuscle masses (Ikeda, 1901 - p. 534, fig. 13; and own data), while $P$. vancouverensis larvae have a single ventral blood corpuscle mass (Zimmer, 1964). The larvae share other characteristics, including number of tentacles and body length before metamorphosis, pigmentation of epidermis, presence of frontal organ and two pairs of black spots on the preoral lobe edge, unpaired stomach diverticulum.

5.3. Actinotrocha harmeri Zimmer, 1964 (the larva of Phoronopsis harmeri) (Fig. 7H)

These larvae are numerous in the plankton of Sea of Japan from the end of August to the end of November. In late October, the density of these larvae can reach up to $1000 \mathrm{ind} . / \mathrm{cm}^{3}$ (own data).

DIAGNOSTIC FEATURES. Larvae are transparent (Fig. 7H). Coelomic cylinder in preoral lobe is present (Fig. 7H). Maximal number of tentacles is 24; body length is $1.5 \mathrm{~mm}$. Competent larvae possess four blood corpuscle masses located on each side of esophagus and stomach diverticulum. Additional blood masses 
(three or four) can appear right before metamorphosis. Juvenile tentacles are absent. Frontal (piriform) organ is present.

COMMENT. A. harmeri has been described by Zimmer (1964) under the name Actinotrocha A. According to Zimmer, competent Actinotrocha $A$ possesses four blood masses. By own data, directly before metamorphosis the number of blood masses was found to be able to increase from four to seven or eight in some larvae.

6. Actinotrochs of the Puget Sound (San Juan Archipelago) (Figs 1B, 8)

Larvae were collected in September 2006.

DESCRIPTION. Larvae are transparent (Fig. 8A). Coelomic cylinder lies under neural plate in preoral lobe (Fig. 8C). At the stage with 16 tentacles, the larvae have a body length of 0.9 mm (Fig. 8A). Two blood masses are situated on the border between preoral lobe and trunk (Fig. $8 \mathrm{~B})$. Stomach diverticulum is unpaired, but there are two ventrolateral septums protruding into the stomach (Fig. 8A). There are numerous large black amoebocytes in the protocoel (Fig. $8 \mathrm{C}$ ), in the blastocoelic cavity and among erythrocytes (Fig. 8B).

COMMENT. These larvae probably belong to Phoronopsis harmeri. Interesting that the larvae of this species in the Vostok Bay are lacking black amoebocytes (see Fig. 7H). Nevertheless, Zimmer (1964; fig. 116) described «pigmentiferous amoebocyte» in the tentacles of Actinotrocha harmeri.

7. Actinotrochs of the Sea of Okhotsk (Fig. 1A).

The larvae of $P$. ijimai, $P$. muelleri and those presumably belonging to $P$. albomaculata occur in the Sea of Okhotsk. Diagnostic features of $P$. ijimai larva were given above.

7.1. Terpeniya Bay (East Sakhalin) (Figs $7 \mathrm{E}-\mathrm{G})$.

Phoronid larvae were found in planktonic samples from Terpeniya Bay. All larval stages were described in our previous work (Temereva, Kulikova, 2007). In this study, the larvae from Terpeniya Bay are assumed to belong to Phoronis muelleri. But these larvae differ from Actinotrocha branchiata described above in this paper from the Mediterranean Sea, and also from those described by Wagener (1847) and Masterman (1898). Therefore, it is necessary to provide designation features of the actinotrochs from the Terpeniya Bay.

DIAGNOSTIC FEATURES. Larvae are transparent (Fig. 7E). Coelomic cylinder in preoral lobe is absent (Fig. 7G). Maximal number of tentacles is 24; body length is $0.9 \mathrm{~mm}$. Two blood masses are situated on dorsolateral sides on the border between preoral lobe and collar region. Stomach diverticulum is unpaired and possesses very thin walls (Fig. 7G). Juvenile tentacles look like small ectodermal sacs under the basis of larval tentacles (Fig. 7F). Frontal organ is present and visible externally (Fig. 7E).

COMMENT. In the Terpeniya Bay, three phoronid species occur, Phoronis muelleri, $P$. hippocrepia, and P. psammophila. The larvae from Terpenita Bay possess some differences from the Phoronis muelleri larvae. For example, competent larvae do not have paired vacuolated diverticula.

The larvae of $P$. hippocrepia are small, opaque and possess only ten tentacles at maturity. According to these facts we did not compare $P$. hippocrepia larvae and larvae found in the Terpenia Bay.

Can larvae found in the Terpenia Bay belong to $P$. psammophila? It can, but according to Emig (2009), P. psammophila larvae possess only 12 tentacles and three blood masses. The larvae from the Terpeniya Bay have some similar characters with the larvae described by Cowles (1904) and Brooks and Cowles (1905). The larvae described in these works are about 1 mm long, have ca. 18 tentacles with juvenile ones like thickenings. These larvae possess two blood masses but have no frontal organ. According to Emig (1982) these larvae have been synonymized under Phoronis psammophila.

In the key (see below) the larvae from Terpeniya Bay and $P$. muelleri and $P$. psammophila larvae are separated.

Interesting that 'Actinotrocha D' (see Johnson, Zimmer, 2002) like larvae in Terpenia Bay possesses stomach, which characteristically inflated with sea water and occupies the anterior 


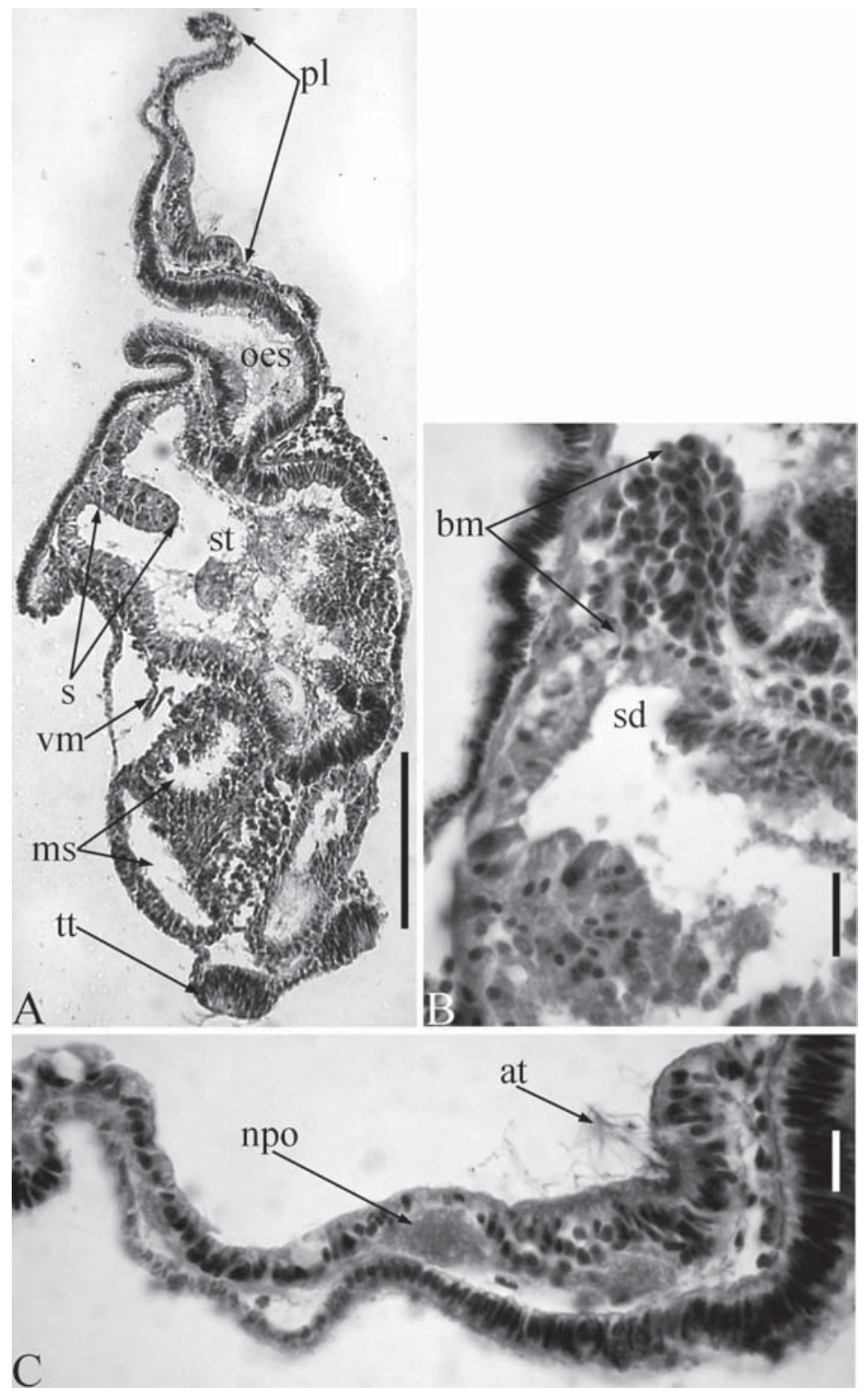

Fig 6. Histological sections of the actinotroch larva of unidentified phoronid species from the Black Sea (light micrograph).

A - parasagittal section through the whole larva (ms metasomal sac; pl preoral lobe; es esophagus; $\mathrm{s}$ epithelial septum in the stomach - st; tt perianal ciliated ring; vm ventral mesentery). B - longitudinal section through blood mass (bm) situated on the stomach diverticulum (sd). C - longitudinal section through the preoral lobe (at apical tuft; nfo frontal organ neuropile). Scale bars: A $-100 \mu \mathrm{m} ; \mathrm{B}, \mathrm{C}-10 \mu \mathrm{m}$.

Рис. 6. Гистологические срезы актинотрохи неопределенной видовой принадлежности из Черного моря.

A - парасагиттальный срез через личинку (ms метасомальный мешок; $\mathrm{pl}$ преоральная лопасть; еs пищевод; $\mathrm{s}$ эпителиальная септа в желудке - st; tt телотрох; vm вентральный мезентерий). В — продольный срез через скопление эритроцитов (bm), расположенное на дивертикуле желудка (sd). C - продольный срез через преоральную лопасть (at теменной султанчик; nfo нейропиль фронтального органа). Масштабы: A - 100 мкм; $\mathrm{B}, \mathrm{C}-10$ мкм. 


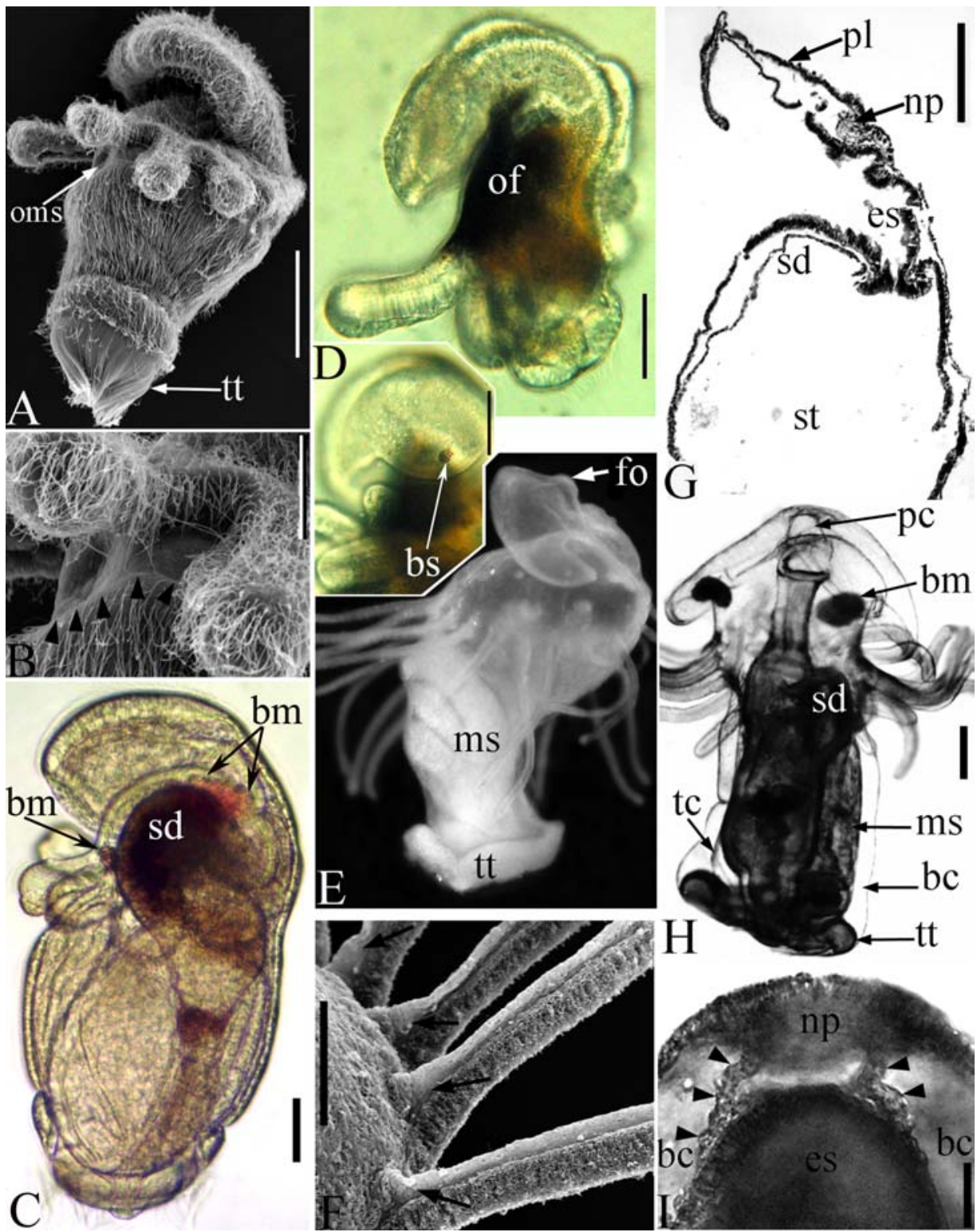

Fig. 7. Actinotrochs larvae.

A-C - Actinotrocha sp. A - general view of larva from scanning microscope (oms - opening of metasomal sac; $\mathrm{tt}$ - cilia of perianal ciliated ring). B - epithelial belt lacking cilium under tentacles (the border of belt marking by arrowheads). C - general view of living larvae from light microscope (sd - pigmented stomach diverticulum; bm blood masses). D - Phoronis ijimai young larva with black pigmented epithelium of oral field (of). D-insert - the preoral lobe of Phoronis ijimai 14-tentacled larvae with the black spot (bs) on the edge. E-G - larvae from the Terpeniya Bay. E - general view of fixed larvae from light microscope ( $\mathrm{ms}$ - metasomal sac; fo — frontal organ). F — primordia of juvenile tentacles (shown by arrows) under larval tentacles from scanning microscope. G - sagittal section from larva with 14 tentacles (np — apical plate; $\mathrm{pl}$ — preoral lobe; es — esophagus; sd — stomach diverticulum; st stomach). $\mathrm{H}$ light micrograph of Phoronopsis harmeri 18-tenacled larva (bc - blastocoel; $p c$ border of preoral coelom; tc — border of trunk coelom; ms - metasomal sac; sd — stomach diverticulum; $\mathrm{tt}$ - perianal ciliated ring). I — part of preoral lobe of the Phoronopsis albomaculata larva. Borders of preoral coelom showed by arrowheads (np — apical plate; bc blastocoel; es - esophagus). Scale bars: A, D, F - $60 \mu \mathrm{m}$; B, I - $20 \mu \mathrm{m}$; C, E, G, H - $100 \mu \mathrm{m}$; D-insert - $140 \mu \mathrm{m}$. 
half of the trunk cavity. Possibly it is an adaptation for hover in the volume of the water.

7.2. South-Kurilskiy Strait (Figs 2F, 7I).

A phoronid larva was found in a sample taken in August 2005 in the South-Kurilskiy Strait. This larva is assumed to be Phoronopsis albomaculata.

DESCRIPTION. Larva is transparent. In the preoral lobe under neural plate, there is a cylindrical-shaped preoral coelom seen though transparent integument(Fig. 7I). The larva possesses 16 tentacles with a length of $0.20 \mathrm{~mm}$ (Fig. 2F). Body length is $0.40 \mathrm{~mm}$. The preoral lobe diameter is $0.21 \mathrm{~mm}$. Stomach diverticulum is unpaired (Fig. 2F). Two blood masses are situated on each dorso-lateral side close to the border between preoral lobe and collar region (Fig. $2 \mathrm{~F})$. In the end of trunk, a well-developed perianal ciliated ring is situated.

COMMENT. The larva described above is ascribed to the genus Phoronopsis because of its cylindrical-shaped preoral coelom under neural plate (Fig. 7I).

Only two species of adult Phoronopsis were described from the Far Eastern Seas of Russia, $P$. harmeri and P. albomaculata (Emig, Golikov, 1990). The larva described above is not similar to the larva of Phoronopsis harmeri at the 16-tentacle stage. It should possess a thick and dark pigmented stomach diverticulum, body length of ca. $0.70-0.75 \mathrm{~mm}$ and different ratios between body length, diameter of preoral lobe and tentacle length (see Temereva, Malakhov, 2007). Therefore, the larva from the South-
Kurilskiy Strait belongs to $P$. albomaculata. The larva of $P$. albomaculata (Actinotrocha albomaculata) was not known until now.

\section{Conclusions}

The world phoronid fauna is evidently much richer than currently recognized. Several of the unidentified actinotroch larva types described here belong to new species. Phoronid larvae as well as adults have very uncertain diagnostic features. This problem was noted in the work of Santagata and Zimmer (2002) and could be approached using molecular phylogenetic methods.

Phoronids possess three main types of development

- holopelagic (all stages of development - from egg to metamorphosis - proceed in water),

- development with brooding (all stages of early development — from egg to young larva - proceed in brood mass in lophophoral concavity),

- lecithotrophic.

According to each type of development, three types of larvae could be recognized.

The larvae of almost all phoronids with holopelagic development (except for Phoronis pallida) have large size (body length is more than $1 \mathrm{~mm}$ ), are transparent and have no pigmented integument; they possess greater spaces of blastocoel in the preoral lobe and in the trunk. Prior to metamorphosis, these larvae possess numerous tentacles which minimal number is

Рис. 7. Личинки форонид.

A-C - Actinotrocha sp. A — общий вид личинки по данным SEM (oms - отверстие метасомального мешка; $\mathrm{tt}$ жгутики телотроха). В - участок эпидермиса под щупальцами, лишенный жгутиков (граница участка указана наконечниками). C - общий вид личинки в световой микроскоп ( $\mathrm{sd}$ - пигментированный дивертикул желудка; bm - скопления эритроцитов). D - молодая личинка Phoronis ijimai с пигментированным эпидермисом орального поля (of). D-вставка - преоральная лопасть личинки Phoronis ijimai на стадии 14 щупалец, вблизи края лопасти заметно одно темное пигментное пятно (bs). E-G - личинки из зал. Терпения. Е - общий вид фиксированной личинки в световой микроскоп (ms - метасомальный мешок; fo - фронтальный орган). F зачатки ювенильных щупалец (указаны стрелками) под личиночными щупальцами по данным SEM. G сагиттальный срез через личинку на стадии 14 щупалец (np — апикальная пластинка; $\mathrm{pl}$ — преоральная лопасть; es — пищевод; sd — дивертикул желудка; st — желудок). Н — личинка Phoronopsis harmeri на стадии 18 щупалец (bc - бластоцель; $\mathrm{pc}$ - граница предротового целома; tc — граница туловищного целома; $\mathrm{ms}$ - метасомальный мешок; sd - дивертикул желудка; $\mathrm{tt}$ - телотрох). I - участок преоральной лопасти личинки Phoronopsis albomaculata. Границы преорального целома показаны наконечниками (np - апикальная пластинка; bc бластоцель; еs - пищевод). Масштабы: А, D, F - 60 мкм; В,I - 20 мкм; C, E, G, H - 100 мкм; D-вставка 140 мкм. 

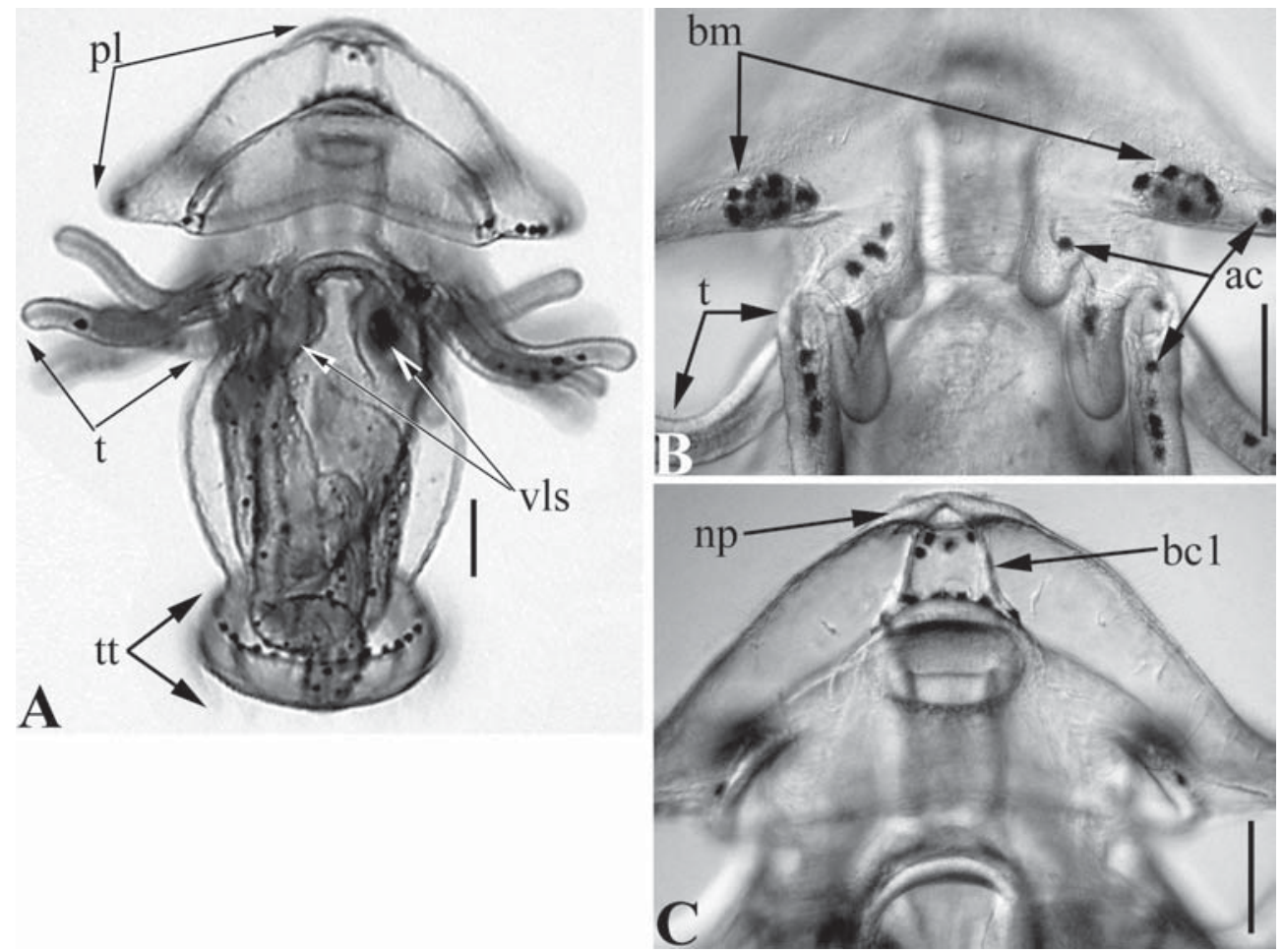

Fig. 8. Larva of Phoronopsis harmeri of Puget Sound (photos of live animals).

A — general view of larva. B — view of dorsal side. C - coelomic cylinder in preoral lobe. Abbreviations: ac — black amebocytes; bm — blood mass; $\mathrm{np}$ — apical plate; $\mathrm{pl}$ — preoral lobe; $\mathrm{t}$ — tentacles; $\mathrm{tt}$ — perianal ciliated ring; vls ventrolateral septa of the stomach. Scale bar: $0.1 \mathrm{~mm}$.

Рис. 8. Личинка Phoronopsis harmeri из зал. Пюджет Саунд (фотографии живых животных).

A 一 общий вид личинки. В - вид на преоральную лопасть и зону закладки новых щупалец (дорсальная сторона). $\mathrm{C}$ - целомический цилиндр в преоральной лопасти. Обозначения: ac - черные амебоциты; bm - скопления эритроцитов; $\mathrm{np}$ — апикальная пластинка; $\mathrm{pl}$ — преоральная лопасть; $\mathrm{t}$ — щупальца; $\mathrm{tt}$ — телотрох; vls — вентролатеральные септы в желудке. Масштаб 0,1 мм.

24. Actinotrochs spread long numerous tentacles and hover in water. Their style of movement resembles the style of echinoderms' larvae: actinotrochs slowly hover in the volume of the water with tentacles moving apart. Larvae of phoronids with holopelagic development live in plankton for about 2.5-3 months (according to own data about $A$. harmeri).

Based on these facts, P. albomaculata, $P$. californica, and P. malakhovi having transparent larvae are ascribed to the holopelagic type of development.

The larvae of almost all phoronids with brooding development (except for Phoronis psammophila) have small size (body length is less than $1 \mathrm{~mm}$ ), dense opaque and pigmented integument. The spaces of blastocoel are narrowed up to thin basal laminae between epithelia. Usually the blastocoel in preoral lobe possesses the largest volume, but in some cases ( $A$. vancouverensis and some other) it is lacking. Small dense actinotrochs have very short tentacles; the number of that does not exceed 14 . These phoronid larvae possess extremely powerfully developed perianal ciliated ring. It is formed by very long thick flagellums and serves as the main engine for swimming. Actinotrochs move in water very quickly, rotating around the axis. Their style of movement resembles the style of trochophores: actinotrochs quickly move 
in the volume of the water revolving on own axis. Small mobile actinotrochs live in plankton for about 1 month.

Only Phoronis ovalis possesses lecitotrophic larvae that develops from big egg $(125 \mu$ in diameter) and is not swimming and feeding.

\section{A Key to Phoronid LaRvae}

1(14). Larvae are transparent 2

2(7). Larvae possess cylindrical-shaped preoral coelom in preoral lobe under apical plate ......... 3

3(6). At the stage with 16 tentacle, larvae possess two blood masses situated on the border between preoral lobe and collar region 4

4(5). Larvae with 16 tentacles have a body length of $0.75 \mathrm{~mm}$ Phoronopsis harmeri

(“Actinotrocha harmeri»)

5(4). Larvae with 16 tentacles have a body length less than $0.45 \mathrm{~mm}$

. presumably Phoronopsis albomaculata («Actinotrocha albomaculata»)

6(3). The blood masses are lacking at least at the stage with 26-28 tentacles . ............ presumably Phoronopsis californica («Actinotrocha californica»)

7(2). Closed cylindrical-shaped coelomic cavity in preoral lobe is absent

8

$8(13)$. Stomach diverticulum is unpaired ............ 9

9(10). There is a single blood mass situated on the ventral side of stomach diverticulum. Larvae with 18 tentacles have a body length of $0.4 \mathrm{~mm}$ Actinotrochs of the Black Sea

10(9). The number is more than one .................. 11

11(12). There are two blood masses situated on the border between preoral lobe and collar region. Maximal number of tentacles is 24 Actinotrochs of the Terpeniya Bay

12(11). There are three blood masses (one on the ventral side of stomach diverticulum and two on the border between preoral lobe and collar region). Maximal number of tentacles is 12 ......

.. Phoronis psammophila («Actinotrocha sabatieri»)

13(8). Stomach diverticulum is paired Phoronis muelleri («Actinotrocha branchiata»)

14(1). Larvae are opaque

15(16). There are four black spots on the edge of preoral lobe. The epidermis of most body surface is heavily pigmented Phoronis ijimai

(«Actinotrocha vancouverensis»)

16(15). Black spots on the edge of preoral lobe are lacking

... 17

17(18). There is heavily black pigmentation of stomach diverticulum epitheium. Competent larvae possess three blood masses «Actinotrocha sp.»

18(17). Heavily black pigmentation of stomach diverticulum epitheium is lacking. The number of blood masses is other than three .................... 19

19(20). There are two blood masses situated on the border between preoral lobe and collar region Phoronis hippocrepia

(«Actinotrocha hippocrepia»)

20(19). There is a single blood mass on the ventral side of stomach diverticulum .... Phoronis pallida («Actinotrocha pallida»)

\section{Acknowledgments}

I am most grateful A.V. Chernyshev, M. Chikina, S. Maslakova, and S. Slobodov. Special thanks for my friend $\mathrm{K}$. Gongalskiy for the help with manuscript preparation. The project was funded by the Russian Foundation for Basic Research (project \# 08-04-00991).

\section{References}

Bartolomaeus T. 2001. Ultrastructure and formation of the body cavity lining in Phoronis muelleri (Phoronida, Lophophorata) // Zoomorphol. Vol.120. P.135-148.

Brooks W.K., Cowles R.P. 1905. Phoronis architecta: its life history, anatomy and breeding habits // Mem. Natnl Acad. Sci. Wash. Vol.10. P.72-113.

Cowles R.P. 1904. Origin and fate of the body-cavities and the nephridia of the Actinotrocha // Zeitschr. f. Zool. Syst. u. Evolutionforsch. Bd.12. S.128-151.

Emig C. 1971. Taxonomie et systematique des Phoronidiens // Bulletin du Muséum d'Histoire naturelle de Paris (Zoologie). T.8. P.69-568.

Emig C. 1974. The systematics and evolution of the phylum Phoronida//Z.Zool. Syst. Evol.-forsch. Bd.12. S.128-151.

Emig C. 1975. Terminology in Phoronida // Zoologica Scripta. Vol.4. P.37-40.

Emig C. 1979. British and other Phoronids // Kermack D.M., Barnes R.S. (eds.). Synopsis of British fauna. London: Acad. Press. 57 p.

Emig C. 1982. The biology of Phoronida// Mar. Biol. Adv. Vol.19. P.2-90.

Emig C. 2009. http://www.com.univ-mrs.fr/DIMAR/ Phoro/

Emig C., Golikov A. 1990. [On phoronids of the Far Eastern seas of the USSR and their distribution in the Pacific Ocean] // Zool. Zhurn. Vol.69. P.22-30 [in Russian with English summary].

Goodrich M. 1903. On the Body-cavities and Nefridia of the Actinotrocha Larva // Quart. J. Mic. Sci. Vol.47. P.103-121.

Halanych K.M., Bacheller J.D., Aguinaldo A.M., Liva S.M., Hillis D.M. 1995. Evidence from 18 S ribosomal DNA that the lophophorates are protostome animals // 
Science. Vol.267. P.1641-1643.

Herrmann K. 1976. Untersuchungen uber Morphologie, Physiologie, und Okologie der Metamorphose von Phoronis muelleri (Phoronida) // Zool. Jahrb., Anat. Bd.95. S.354-426.

Herrmann K. 1986. Ontogenesis of Phoronis muelleri (Tentaculata) with a special sight for differentiation of mesoderm and phylogenesis of coelom // Zool. Jahrb., Anat. Bd.114. S.441-463.

Ikeda I. 1901. Observation on the development, structure and metamorphosis of Actinotrocha // J. Coll. Sci., Imperial University, Tokyo. Vol.13. P.507-591.

Johnson K.B., Zimmer R.L. 2002. Phoronida // C.M. Young, M.A. Sewall and M.E. Rice (eds.). Atlas of Marine Invertebrate Larvae. San Diego: Academic Press. P.429-439.

Kowalevsky A.O. 1867. [Anatomy and development history of Phoronis] // Zapiski Sankt-Petersburgskoi Akademii Nauk. Vol.2. P.1-35 [in Russian].

Masterman A.T. 1898. On the Diplochorda // Quart. J. Mic. Sci. Vol.40. P.281-366.

Müller J. 1946. Bericht über einige Tierformen der Nordsee // Arch. Anat. Phis. Bd.13. S.101-104.

Santagata S. 2002. Structure and metamorphic remodeling of the larval nervous system and musculature of Phoronis pallida (Phoronida)//Evol. \& Dev. Vol.4. P.28-42.

Santagata S, Zimmer R.L. 2002. Comparison of the neuromuscular system among actinotroch larvae: systematic and evolutionary implication // Evol. Dev. Vol.4 P.43-54.

Siewing R. 1974. Morphologische Untersuchungen zum Archicoelomatenproblem. The body segmentation in Phoronis muelleri de Selys-Longchamps (Phoronidea) Ontogenese - Larve - Metamorphose - Adultus // Zool. Jahrb., Anat. Bd.92. S.275-318.

Siewing R. 1980. Das Archicoelomatenkonzept // Zool.
Jahrb., Anat. Bd.103. S.439-482.

Temereva E. 2000. [New phoronid species Phoronopsis malakhovi (Lophophorata, Phoronida) from South China Sea] // Zool. Zhurn. Vol.79. P.1088-1093 [in Russian with English summary].

Temereva E., Malakhov V. 2004. [A key to the identification of Phoronid larvae (Phoronida, Lophophorata) from the Sea of Japan] // Zool. Zhurn. Vol.83. P.11151126 [in Russian with English summary].

Temereva E., Malakhov V., Chernyshev A. 2006. Giant Actinotroch, a Larva of Phoronida from the South China Sea: The Giant Larva Phenomenon // Dokl. Biol. Sci. Vol.410. P.410-413.

Temereva E., Kulikova V. 2007. Larvae of Phoronids from the Terpeniya Bay (Southeastern Sakhalin) // Rus. J. Mar. Biol. Vol.33. P.61-66.

Temereva E, Malakhov V. 2007. Embryogenesis and larval development of phoronid Phoronopsis harmeri Pixell, 1912: dual origin of the coelomic mesoderm // Invert. Reprod. Dev. Vol.50. P.57-66.

Wagener R. 1847. Über den Bau der Actinotrocha branchiata // Arch. Anat., Phys. Bd.14. S.202-206.

Wright T. 1856. Description of two tubicolar animals // Edinburgh New Philos. J. Vol.1. P.165-167.

Zimmer R. 1964. Reproductive biology and development of Phoronida. Ph.D. dissertation. Washington: University of Washington. $416 \mathrm{p}$.

Zimmer R. 1978. The comparative structure of the preoral hood coelom in Phoronida and the fate of this cavity during metamorphosis // Chia F.S., Rice M.E. (eds.). Settlement and Metamorphosis of Marine Invertebrate Larvae. New York: Elsevier. P 23-40.

Zimmer R. 1991. Phoronida // Giese A.C., Pearse J.S., Pearse V.B. (eds.). Reproduction of Marine Invertebrates. Echinoderms and Lophophorates. CA: Boxwood Press. P.1-45. 